\title{
THE VARIATION OF RHYNCHONELLA BOUETI
}

SIR,--It was with great interest that I read the letters referring to the variation study of Rhynchonella boueti by Mr. W. G. Aitken and myself (Geol. Mag., Ixxxv, 1948), which you published in your May-June number.

Mr. R. K. Blundell's diagram exhibits the variation of the ratios $L / T$, $T / B$, and $L / B$ in a very similar way to our Text-fig. 10 ; and I would readily agree with him that only two, and not three, independent variables are, in fact, represented-his diagram indicates this clearly. The only advantage of drawing the axes at $60^{\circ}$ (as in our Text-fig. 10) is that the three ratios are then equally represented, whereas if two axes are taken at $90^{\circ}$ to each other one set of ratios is bound to be on a different scale to the other two (e.g. in Mr. Blundell's figure the distance between the lines $\mathrm{L} / \mathrm{B} 0.8$ and $\mathrm{L} / \mathrm{B} 0.9$ is only three-quarters the distance between the lines $\mathrm{T} / \mathrm{B} 0.8$ and $\mathrm{T} / \mathrm{B} 0.9$ ). I may add that I am gratified to find that his scatter confirms so completely our own findings.

In reply to Mr. F. W. Beales I would say that quite certainly the specimens we used did not in all literalness belong to a community of strictly contemporaneous individuals ; but, geologically speaking, the Boueti Bed is so thin (1 foot) and the areal range of the collection is so limited (10 yards along the line of outcrop), that if fossil communities are ever to be recognized, substantially this was one from which our sample was taken. Evidence of exposure of the shells for any length of time, as proved by polyzoan and serpulid incrustations, has no relevance, since a collection of present-day shells on a present-day beach may well show similar overgrowths.

Department of Geology,

W. S. MCKerRow.

UNIVERSITY MUSEUM, OXFORD.

15th July, 1948.

\section{THE RANGE OF THYSANOPHYLLUM PSEUDOVERMICULARE (M'COY)}

SIR,- - In a forthcoming paper in the Transactions of the Leeds Geologists' Association I have recorded the presence of Thysanophyllum pseudovermiculare in a reef-knoll at Ballykane Hill, Co. Kildare, and suggested that the knoll in question may be early $C_{2}$ and so intermediate in age between the $C_{1}$ reeflimestones of $\mathrm{Co}$. Dublin and those of $\mathrm{C}_{2}$ age near Cork. Since passing pageproofs, I have found a number of corallites of the species at Stepsbeck Bridge, Scandal Beck, Ravenstonedale, at an horizon between the globosus-Band and the underlying Algal Band, and so far below the well-known pseudovermiculare-Band of $\mathrm{C}_{2}$. Dr. C. J. Stubblefield has drawn my attention to what appears to be a still earlier occurrence of the coral, viz. in association with Solenopora garwoodi and Camarotoechia proava in Dukes Wood well no. 146 (Lees and Taitt, 1946, Q.J.G.S., 101, p. 281). Accordingly, there is no reason to regard the Ballykane Hill knoll as younger than the $C_{1}$ reefs of Dublin, to which its brachiopod-fauna is allied.

I am indebted to Dr. Stanley Smith for identifications of the Kildare and Ravenstonedale corals: he informs me that M'Coy's species should be referred to the genus Spongophyllum Edwards and Haime, 1851.

DeParTMENT OF Geology,

J. ŚELWYN TuRner.

UNIVERSITY OF LEEDS.

17 th August, 1948. 